\section{AMERICAN-EURASIAN JOURNAL OF SUSTAINABLE AGRICULTURE}

\title{
Factors Affecting Profit Analysis of Small-Scale Beef Cattle Farmers in the Special Region of Yogyakarta, Indonesia
}

\author{
Ferdian Achmad ${ }^{1,2}$, Jangkung Handoyo Mulyo $^{3}$, Masyhuri ${ }^{3}$, Subejo $^{3}$ \\ ${ }^{1}$ Ph.D. student of Agricultural Economics, Faculty of Agriculture, Gadjah Mada University, Yogyakarta, Indonesia \\ ${ }^{2}$ Inspectorate General, Ministry of Agriculture Republic of Indonesia, Jakarta, Indonesia \\ ${ }^{3}$ Department of Agricultural Economics, Faculty of Agriculture, Gadjah Mada University, Yogyakarta, Indonesia.
}

Received date: 12 February 2019, Accepted date: 15 May 2019, Online date: 3 June 2019

Address for Correspondence:

Ferdian Achmad,Ph.D. student of Agricultural Economics, Faculty of Agriculture, Gadjah Mada University, Yogyakarta, Indonesia ${ }^{2}$ Inspectorate General, Ministry of Agriculture Republic of Indonesia, Jakarta, Indonesia

Copyright $\odot 2019$ by authors and American-Eurasian Network for Scientific Information.

This work is licensed under the Creative Commons Attribution International License (CC BY).

http://creativecommons.org/licenses/by/4.0/

\section{(c) (i) Open Access}

\begin{abstract}
Smallholder farmers mostly maintain small-scale fattening beef cattle farms in Indonesia. The ownership system of beef cattle in smallholder farmers consists of the self-ownership system and the partnership system. This research study aims to analyze the factors that were affecting the profit of small-scale of the beef cattle farmers in the Special Region of Yogyakarta, Indonesia. The research study conducted at 4 (four) regencies in Special Region of Yogyakarta, those are Gunung Kidul Regency, Bantul Regency, Kulonprogo Regency, and Sleman Regency, purposively. Respondents that became the sample of this research study were 240 persons, consisting of 120 self-ownership farmers and 120 partnership farmers fattening type; selecting the samples using the Quota Sampling method. Data were analyzed using Unit Output Price (UOP) Cobb Douglas Profit Function. The results showed that the profit of small-scale of beef cattle farmers with self-ownership systems in Special Region of Yogyakarta was higher than the beef cattle farmers with partnership system. Factors that influenced the profit of small-scale beef cattle farmers negatively included depreciation cost of barn and equipment, the price of calves (fattening cattle), the price of forage feed, price of concentrate feed, and wage labor. The added value of the five variables tends to reduce the profits obtained by the farmers. While the factors that influenced positively were the variable of the amount of beef cattle production, type of beef cattle, and cattle ownership system, the addition of the number and fulfillment of the three variables would increase the profit of beef cattle farmers.
\end{abstract}

KEYWORDS

Beef Cattle; Cobb Douglas Profit Function; Fattening; Partnership; Small-scale; Self-ownership.

\section{INTRODUCTION}

Food self-sufficiency is one of the target programs of the Ministry of Agriculture of the Republic of Indonesia which must be realized immediately, including autonomy in rice, corn, soybeans, and increasing beef and sugar production [17]. Beef is one of the strategic types of food that the output must increase because currently, there is a deficit in commodity demand for beef compared to the total population of Indonesia. This condition is expected to affect the inadequate fulfillment of the needs of the Indonesian people for beef and its processed products in the future, as one source of animal protein.

The population of beef cattle in Indonesia for the last five years until the end of 2017 was to $16,599,247$ or equivalent to 531,757 tons, but still experiencing a deficit [18]. The majority of the distribution of beef cattle in Indonesia is dominated by small-scale farmers, which is $97.97 \%$, while the remaining is only $2.03 \%$; controlled 
by big livestock companies [3]. Production inputs used in beef cattle farm by small-scale farmers are still limited and not entirely able to be fulfilled by farmers. The bargaining power of farmers to obtain optimal profits also constrained by obstacles in the marketing process controlled by middlemen or intermediaries (broker).

The limited capital access experienced by small-scale farmers in Indonesia, which has a low income, has led to the emergence of a partnership system of beef cattle ("gaduhan"). Most of the beef cattle farms in Indonesia that run this system are performed between farmers and the closest neighbors and between farmers and relatives they know, mostly through verbal agreements without written agreements. According to [35], the agreement of beef cattle partnership system in Indonesia based on friendship and family relationship based on the principle of mutual trust, interdependence, and need. This statement is in line with the opinion that the pattern of private partnership in Indonesian rural area adopted due to mutual benefits and relationship of social factors. For example, financiers are respected community leader. Therefore, the breeder feels more responsible for the cattle, even though the partnership pattern does not have good records [34].

According to [27], partnership system of beef cattle farm with a profit-sharing system, states that agreements of the profit sharing system can be divided as follows: agreements with the delivery of livestock to a person for a certain period of time maintained with the intention to sell and share the profits, or the value estimated at the beginning and the end of the agreement and added value or depreciation of value will be shared, and agreements in which newborn beef cattle sold and the profits will share. This makes the basis of the benefit obtained will share with livestock owners or those who entrust their livestock to the breeder. The percentage of profit sharing from observations in the field includes 50:50 and 60: 40 for breeder and owner. The opinion of [20] also stated that profit sharing is a collaboration with a profit-sharing agreement of 50\%: 50\%. This system is mostly because of poverty and the difficulty in obtaining capital that usually forces someone to accept to be willing to work on the field or raising livestock that is not his own.

Special Region of Yogyakarta as one of the provinces of Ongole breeds in Indonesia had livestock population of 314,620 at the end of 2017, consisting of 52,078 in Kulonprogo Regency, 57,118 in Bantul Regency, 151,201 in Gunungkidul Regency, 54,123 in Sleman Regency, and 100 in Yogyakarta. Compared to household and non-household consumption needs, there was still a deficit of 16,284 tons of beef [6]. Selfownership and partnership breeding system performed by small-scale farmers has not been able to meet the needs of the beef supply in the Special Region of Yogyakarta. This has become a tremendous opportunity for small-scale farmers to increase their production capacity, while at the same time trying to improve the profits than expected to obtain.

Some previous research studies related to the profit of beef cattle stated that [14] the average advantage of farmers in upland was greater than farmers in the lowland, with variables that affected benefits such as the number of livestock owned, and the selling price of livestock. [12] stated that the contribution of income from beef cattle business from total household income in Tanah Laut Regency, South Kalimantan Province ranged from 15-26\%, while the results of analysis [19] in South Africa were 19\%. Whereas, the variables of beef cattle farmer education and livestock business increased in farmer income in East Java, Indonesia [33]. [30] stated that the income of fattening beef cattle farmers (traditional profit-sharing system) in South Sulawesi Province for six months of breeding is IDR 1,635,965 per beef cattle, larger than feeder cattle pattern. From the previous research studies, the expected novelty of this research study is the calculation of profit rate and the factors that influence it through comparison between self-ownership farmers and partnership farmers, using several variables, including dummy variables predicted by a researcher that also affect the profit.

Based on the background of the problem, there is a difference in the level of profit of the fattening beef cattle farmers between self-ownership systems and partnership systems, therefore the main objective and the aim of this research study is to analyze the factors that influence the profit of small-scale of beef cattle farmers in the Special Region of Yogyakarta, Indonesia.

\subsection{Research Location and Sampling Method}

\section{MATERIALS AND METHODS}

This research study conducted from January to March 2018. The research location was in the province of Special Region of Yogyakarta. It was determined based on the purposive sampling method, and those were at 4 (four) regencies in Special Region of Yogyakarta; Gunungkidul Regency, Bantul Regency, Kulonprogo Regency, and Sleman Regency. The data used were primary data and secondary data. Primary data was obtained by surveying the fattening beef cattle by small-scale farmers in each regencies using a structured questionnaire while secondary data taken from the Central Bureau of Statistics (BPS), and Agricultural Office (Provincial and Regency).

The total population of respondents in this research study was 240 farmers, consisting of 120 selfownership farmers, and 120 partnership farmers, with details of each regency, were taken 30 self-ownership 
Ferdian Achmad et al., 2019. Factors Affecting Profit Analysis of Small-Scale Beef Cattle Farmers in the Special Region of Yogyakarta, Indonesia / American-Eurasian Journal of Sustainable Agriculture. 13(2): 1-12. DOI: $10.22587 /$ aejsa.2019.13.2.1

farmers, and 30 partnership farmers. The sampling method in this research study used Quota Sampling [7,8], that was the sample chosen and determined without considering the population as a sample frame because it was very heterogeneous in terms of number. Moreover, the selected respondent was deemed to be able to provide explanations that were close to the truth.

\subsection{Data Analysis}

The comparison between the profit rate between self-ownership farmers and partnership farmers in Special Region of Yogyakarta was measured using the calculation of total revenue, total cost, and profit per respondent [31], both self-ownership farmers and partnership farmers. The benefit of small-scale farmers in this research study obtained from the difference between the total costs spent by the farmers (fixed + variable value) with total revenue earned during the breeding period of fattening ( 8 to 10 months).

According to [36], the profit function ( $\pi$ ) was the Total Value Production (TVP) minus the Total Cost (TC). To identify the factors that influenced the profit function analyzed the livestock business income. The profit function equation derived from the production function equation. The data was analyzed using the Unit Output Price (UOP) Cobb Douglas Profit Function, by dividing the price of each input with the output price (in IDR), then transformed into natural logarithms $[10,23,14,11]$. [36] makes a derivative of the profit function equation derived from the production function as follows:

$Y=F\left(X_{1}, \ldots, X_{m} ; Z_{1}, \ldots Z_{n}\right)$

where:

Y: Output

$\mathrm{X}_{\mathrm{i}}$ : Variable input

$Z_{j}$ : Fixed input

Based on the profit function in the equation, the profit function formulated as follows:

$\pi=P Y\left(X_{1}, \ldots, X_{m} ; Z_{i}, \ldots, Z_{n}\right)-\sum_{t=1}^{m} C_{i} X_{i}$

where:

$\pi$ : Profit

P: Output price per unit

Y: Total output

$\mathrm{X}_{\mathrm{i}}$ : Variable input

$\mathrm{Z}_{\mathrm{j}}$ : Fixed input

$\mathrm{C}_{\mathrm{i}}$ : Price of the production factor for the I variable

Using the Cobb-Douglas production function, the normalized profit function in natural logarithm is written as follows [36]:

$\ln \pi^{*}=\ln A^{*}+\sum_{t=1}^{m} \alpha_{i} \ln C_{i}^{*}+j=1 \sum_{t=1}^{n} \beta_{j}^{*} \ln Z_{j}$

where:

$\pi * \quad:$ Normalized profit

A * : Intercept

$\alpha_{\mathrm{i}} \quad:$ The variable production factor price coefficient

$\beta_{\mathrm{j}} * \quad$ : Fixed production factor coefficient

$\mathrm{C}_{\mathrm{i}} * \quad$ : Normalized price of production factors

$\mathrm{Z}_{\mathrm{j}} \quad$ : Quantity of fixed production factor

Based on these equations, the analysis model in this research study could arrange as follows:

$\ln \pi^{*}=\ln \alpha_{0}+\alpha_{1} \ln$ Prod $+\alpha_{2} \ln$ Peny $+\beta_{3} \ln$ PBit $+\beta_{4} \ln$ PHij $+\beta_{5} \ln$ PKon $+\beta_{6} \ln$ PObat $+\beta_{7} \ln$ PNaker $+\beta_{8}$ ln PSupl $+\mathrm{d}_{1}$ DDik $+\mathrm{d}_{2}$ DSapi $+\mathrm{d}_{3}$ DPok $+\mathrm{d}_{4}$ Dist $+\mathrm{u}$

where:

$\pi \quad:$ Normalized farmers profit with output price (IDR/period)

$\alpha_{0} \quad$ : Intercept

$\alpha_{\mathrm{i}}, \beta_{\mathrm{i}} \quad$ : Regression coefficient

$\mathrm{d}_{\mathrm{i}} \quad$ : Dummy coefficient

Prod : Beef cattle production $(\mathrm{kg} /$ period)

Peny : Depreciation cost of barn and equipment (IDR/period)

PBit : Normalized price of calves (fattening cattle) (IDR/period) 
Ferdian Achmad et al., 2019. Factors Affecting Profit Analysis of Small-Scale Beef Cattle Farmers in the Special Region of Yogyakarta, Indonesia / American-Eurasian Journal of Sustainable Agriculture. 13(2): 1-12. DOI: 10.22587/aejsa.2019.13.2.1

PHij : Normalized price of forage feed (IDR/kg/period)

PKon : Normalized price of concentrate feed (IDR $/ \mathrm{kg} / \mathrm{period}$ )

PObat : Normalized price of cattle medicine (IDR/dosage/period)

PNaker : Normalized cost/ wage of labour (IDR/period)

PSupl : Normalized price of supplement feed (IDR/kg/period)

DDik : Dummy of a length of education level $(1=>$ nine years; $0=<9$ years $)$

DSapi : Dummy of cattle type $(1=$ crossbreed; $0=$ local breed $)$

DPok : Dummy of membership of livestock group ( $1=$ joined; $0=$ unjoined $)$

DSist : Dummy of ownership system (1= self-ownership; $0=$ partnership)

u : error term

The estimation of the profit function was performed using the Ordinary Least Square (OLS) method. The classical assumption test was using multicollinearity test, heteroscedasticity test, and normality test, while for the goodness of fit would be measured from the coefficient of determination $\left(\mathrm{R}^{2}\right)$, F-test, and T-test.

\section{Characteristics of Respondents}

\section{RESULT AND DISCUSSION}

Table 1 shows the characteristics of small-scale beef cattle farmers in the Special Region of Yogyakarta (the respondents to this research study). Male farmers dominate the gender of the farmers of the self-ownership system and partnership system, that is 118 persons $(98.33 \%)$ and 111 persons $(92.50 \%)$. This is in line with the opinion of [2] and [21], which suggested that beef cattle farmers were dominated by men, because it required more physical, while the woman (wife) also helped her husband (man) in breeding the beef cattle that cultivated together. The desire in breeding beef cattle was to get additional income and empower family workers; wife and old person [26].

Table 1. Socioeconomic Characteristics of the Beef Cattle Farmers Respondents (n=240)

\begin{tabular}{|c|c|c|c|c|}
\hline \multirow{2}{*}{ Variable } & \multicolumn{2}{|c|}{ Self-ownership Farmers } & \multicolumn{2}{|c|}{ Partnership Farmers } \\
\hline & Frequency (person) & Percentage $(\%)$ & Frequency (person) & Percentage (\%) \\
\hline \multicolumn{5}{|c|}{ Gender } \\
\hline Male & 118 & 98.33 & 111 & 92.50 \\
\hline Female & 2 & 1.67 & 9 & 7.50 \\
\hline \multicolumn{5}{|c|}{ Age (years) } \\
\hline$<30$ & 2 & 1.67 & 4 & 3.33 \\
\hline $30-40$ & 18 & 15.00 & 16 & 13.34 \\
\hline $41-50$ & 37 & 30.83 & 28 & 23.33 \\
\hline $51-60$ & 34 & 28.34 & 45 & 37.50 \\
\hline$>60$ & 29 & 24.16 & 27 & 22.50 \\
\hline \multicolumn{5}{|c|}{ Education Level (years) } \\
\hline $0-6$ & 69 & 57.50 & 63 & 52.50 \\
\hline $6-9$ & 19 & 15.83 & 24 & 20.00 \\
\hline $9-12$ & 27 & 22.50 & 29 & 24.17 \\
\hline$>12$ & 5 & 4.17 & 4 & 3.33 \\
\hline \multicolumn{5}{|c|}{ Number of Family Members (person) } \\
\hline $1-3$ & 96 & 80.00 & 91 & 75.83 \\
\hline $4-5$ & 22 & 18.33 & 26 & 21.67 \\
\hline$>6$ & 2 & 1.67 & 3 & 2.50 \\
\hline \multicolumn{5}{|c|}{ Beef Cattle Farming Experience (years) } \\
\hline$<10$ & 23 & 19.17 & 29 & 24.16 \\
\hline $10-20$ & 57 & 47.50 & 49 & 40.83 \\
\hline $21-30$ & 29 & 24.16 & 17 & 14.17 \\
\hline $31-40$ & 8 & 6.67 & 16 & 13.34 \\
\hline$>40$ & 3 & 2.50 & 9 & 7.5 \\
\hline
\end{tabular}

Source: Primary Data Analysis, 2018

The average age of beef cattle farmers in self-ownership and partnership ownership systems who become respondents to this research study was relatively the same, which was in the range of 41 to 60 years old, the youngest respondent was 23 years old domiciled in Gunungkidul Regency, and the oldest respondent was 84 years old domiciled in Kulon Progo Regency. From the results of the tabulation of data showed that the age of 
Ferdian Achmad et al., 2019. Factors Affecting Profit Analysis of Small-Scale Beef Cattle Farmers in the Special Region of Yogyakarta, Indonesia / American-Eurasian Journal of Sustainable Agriculture. 13(2): 1-12. DOI: 10.22587/aejsa.2019.13.2.1

the farmer respondents in the research study locations had exceeded the productive period, which was in the range of 15 to 55 years. The age of the farmer would affect physically in doing work and making decisions in running a livestock business. From the Table 1 above it can be illustrated that beef cattle business of farmers is one of the economic activities that have taken root in the community, because evenly it is done by farmers with ages above 45 years old, some of them are to meet the household needs, as social status, as well as for savings if there are an individual needs/family needs [35].

The average education level of beef cattle farmers was an elementary school of 69 persons $(57.50 \%)$ of selfownership farmers, and 63 persons $(53.50 \%)$ of partnership farmers. This data showed that the majority of beef cattle farmers with a self-ownership system and partnership system had a low education level; it caused by the farmers did not have the tuition fees. Moreover, most farmers were located very far in the rural interior, and the motives of most beef cattle farmers were only as a side business. According to [13], the level of education would significantly influence the improvement of technical efficiency of beef cattle farmers in allocating production inputs so that it would affect the outputs.

Beef cattle breeding activities with self-ownership system and partnership fattening patterns were mostly handled and performed by farmers and their family members. The number of family members both selfownership and partnership farmers mainly were 1 to 3 person, those were 96 persons $(80.00 \%)$ and 91 persons (75.83\%), with an average of 2.5 and 2.6 persons. The addition of family members would positively correlate and affect the livestock business because there was additional energy in taking care of the family's beef cattle. The contribution of a family member of farmers (father, mother, and child) in cattle income was relatively higher than the income of non-contribution of a family member of farmers that was $48.16 \%$ of the total revenue of beef cattle [5].

Beef cattle farmers who became the respondents in this research study were dominated by farmers with livestock business experience for 10 to 20 years, with the average maturity of self-ownership ownership system for 18.7 years and partnership system for 20 years. The expertise of breeding was related to age, in which older farmers usually had more experience than young farmers. The relatively long breeding experience of more than 20 years considered reasonable because many beef cattle farmers in Special Region of Yogyakarta had started their businesses at a relatively young age, inherited from their parents from generation to generation. According to [13], the experience of breeding affected beef cattle production, in which more experienced farmers tend to be more efficient in using production inputs.

\section{Cost Structure, Revenues, and Profit of Beef Cattle in Special Region of Yogyakarta}

The cost component in the beef cattle business owned by farmers in Special Region of Yogyakarta included fixed costs, consisting of depreciation cost of barn and equipment, and variable costs comprising forage costs (calculated), as well as concentrate feed, supplements feed, livestock medicines, wage labor (estimated) and purchases of calves (fattening cattle). Most farmers in real terms did not pay for purchasing forage feed and paying labor/worker. Forage feed given in the form of grass (grass field, lamtoro/ Leucaena leucocephala, and bulrush/ Pennisetum purpureum) obtained from gathering grass on private land or vacant land. Labor who took care of beef cattle was entirely from the family of the farmers (father, mother, and child); there was no use of labor from outside the family. Calculation of the components cost of forage feed and wage labor in this research study considered. On average, traditional farmers in Indonesia rarely bought forage feed but gathering grass by themselves relying on their employment and family members $[9,14]$.

Table 2. Average of Cost, Revenue, and Profit of the Smallholder Beef Cattle Farmers ( $n=240$

\begin{tabular}{|l|c|c|}
\hline \multicolumn{1}{|c|}{ Component } & Self-ownership Farmers (IDR) & Partnership Farmers (IDR) \\
\hline Total Revenue (TR) & $25,725,200$ & $21,775,400$ \\
\hline Total Fixed Cost (TFC) & 135,548 & 150,510 \\
\hline Depreciation Cost of Barn and Equipment & 135,548 & 150,510 \\
\hline Total Variable Cost (TVC) & $22,969,278$ & $19,720,114$ \\
\hline Cost of Forage Feed (calculated) & $5,170,037$ & $5,341,717$ \\
\hline Cost of Concentrate Feed & $3,978,254$ & $1,123,997$ \\
\hline Cost of Supplement Feed & 375,650 & 164,385 \\
\hline Cost of Cattle Medicine & 175,337 & 63,765 \\
\hline Cost of Labor (calculated) & $2,520,000$ & $2,899,000$ \\
\hline Cost of Calves (Fattening Cattle) & $10,750,000$ & $10,127,250$ \\
\hline Total Cost (TC) & $23,104,826$ & $19,870,624$ \\
\hline Profit $(\pi)($ TR - TC) & $2,620,374$ & $1,904,776$ \\
\hline Absris & & \\
\hline
\end{tabular}

Abbreviation: IDR = Indonesian Rupiah (Rp) 
Ferdian Achmad et al., 2019. Factors Affecting Profit Analysis of Small-Scale Beef Cattle Farmers in the Special Region of Yogyakarta, Indonesia / American-Eurasian Journal of Sustainable Agriculture. 13(2): 1-12. DOI: 10.22587/aejsa.2019.13.2.1

Source: Primary Data Analysis, 2018

The details of the calculation of the costs, revenues, and profit components can be seen in Table 2 . The average cost variable of beef cattle business of self-ownership system required more values than a partnership system. The most significant spending in this cost component variable was the spending for the purchase of calves and the cost of forage feed (calculated). In the context of using forage feed as the primary input that determined the success of fattening beef cattle, if taken into account, self-ownership farmers paid an average of IDR 5,170,037, while for partnership farmers spent an average of IDR 5,341,717. This was because partnership farmers and their families had more free time to gather forage feed, while most self-ownership farmers had other side jobs. Therefore, the quantity of forage fulfilled by partnership farmers had become more abundant. Spending on paid labor for family (calculated) for self-ownership farmers of IDR 2,520,000 was smaller than partnership farmers that were IDR 2,899,000.

Spending on the cost of purchasing concentrated feed and supplements were more costly for self-ownership farmers than partnership farmers, which were IDR 3,978,254 and IDR 1,123,997 as well as IDR 375,650 and IDR 164,385 . This was because self-ownership farmers had more capital resources so that they can buy more concentrates. The concentrate feed usually given to beef cattle in the form of rice bran, Pollard, tofu dregs, and kitchen salt. Feed supplement that often used in the form of branded products and a combination of a mixture of herbal plants, such as kencur or aromatic ginger/ Kaempferia galanga L, turmeric/ Curcuma longa, and java ginger/ Curcuma xanthorrhiza.

The fixed costs of the beef cattle business in this research study were limited to spending in the form of depreciation of barn infrastructure and equipment used. Depreciation costs calculated from the cost of construction and materials for making simple barn divided by economic age, as well as calculations for equipment that was often used by farmers, including sickles, ropes, buckets, and shovels. Between the two systems of ownership of beef cattle in Special Region of Yogyakarta, the total fixed costs of self-ownership farmers of IDR 135.548 was higher than partnership farmers who were IDR 150,510.

From the calculations according to Table 2, the total cost of livestock business (variable costs and fixed costs) of self-ownership farmers of IDR 23,104,826/tail/period was more significant compared to partnership farmers that were IDR 19,870,624/tail/period. From the recapitulation of the calculation of revenue and cost, the average profit for livestock business for beef cattle farmers with self-ownership ownership system was more significant than the profit received by beef cattle farmers with partnership ownership system in Special Region of Yogyakarta, that valued at IDR 2,620,374/tail/period for the profit of self-ownership farmers and IDR $1,904,776 /$ tail/period for the profit of partnership farmers. This condition was in line with the results of the study of [29] which stated that the income of cattle farmers with partnership system was lower than the income of selfownership/ independent farmers.

\section{Factors Affecting The Profit of Beef Cattle Fattening in the Special Region of Yogyakarta}

Based on Table 3, the relationship between the profit of beef cattle business and the factors suspected affecting it were beef cattle production, depreciation of barn and equipment, price of calves (fattening cattle), price of forage feed, price of concentrate feed, price of cattle medicine, wage labor, price of supplement feed, dummy of education level, dummy of beef cattle type, dummy of membership of livestock groups, and dummy of ownership system had an F-statistic value of 1,608,547 showing an authentic relationship with the probability of 0.0000 or with a confidence level of $99 \%$. This indicates that the regression model could be used to predict the profit of farmers from their beef cattle business.

Table 3. Factors that Affecting Profit of the Small-Scale Beef Cattle Farmers in DI Yogyakarta ( $\mathrm{n}=240)$

\begin{tabular}{|c|c|c|c|c|c|}
\hline Variable & $\begin{array}{c}\text { Exp. } \\
\text { Sign }\end{array}$ & Coefficient & $\begin{array}{c}\text { Standard } \\
\text { Error }\end{array}$ & t-stat & Prob. \\
\hline Intercep & $+/-$ & $1,8383 * * *$ & 0,1277 & 14,3860 & 0,0000 \\
\hline $\begin{array}{c}\text { In Beef cattle production (Prod) } \\
\text { ln Depreciation cost of barn and equipment } \\
\text { (Peny) }\end{array}$ & - & $-0,0317 * * *$ & 0,0094 & 3,3760 & 0,0009 \\
\hline $\begin{array}{c}\text { ln Normalized price of calves (PBit) } \\
\text { ln Normalized price of forage feed (PHij) }\end{array}$ & - & $-0,5549 * * *$ & 0,0126 & $-43,9095$ & 0,0000 \\
\hline $\begin{array}{c}\text { ln Normalized price of concentrate feed } \\
\text { (PKon) }\end{array}$ & - & $-0,0456^{* * *}$ & 0,0082 & $-5,5449$ & 0,0000 \\
\hline $\begin{array}{c}\text { In Normalized price of cattle medicine } \\
\text { (PObat) }\end{array}$ & - & $-0,0050 \mathrm{~ns}$ & 0,0040 & $-1,2598$ & 0,2090 \\
\hline $\ln$ Normalized cost/ wage of labor (PNaker) & - & $-0,1536 * * *$ & 0,0067 & $-22,8319$ & 0,0000 \\
\hline
\end{tabular}


Ferdian Achmad et al., 2019. Factors Affecting Profit Analysis of Small-Scale Beef Cattle Farmers in the Special Region of Yogyakarta, Indonesia / American-Eurasian Journal of Sustainable Agriculture. 13(2): 1-12. DOI: $10.22587 /$ aejsa.2019.13.2.1

\begin{tabular}{|c|c|c|c|c|c|}
\hline $\begin{array}{c}\text { In Normalized price of supplement feed } \\
\text { (PSupl) }\end{array}$ & - & $0,0015 \mathrm{~ns}$ & 0,0044 & 0,3492 & 0,7272 \\
\hline Dummy of length of education level (DDik) & + & $-0,0003 \mathrm{~ns}$ & 0,0043 & -0.0704 & 0,9439 \\
\hline Dummy of cattle type (DSapi) & + & $0,0026^{*}$ & 0,0057 & 1,4546 & 0,0649 \\
\hline Dummy of member of cattle group (DPok) & + & $0,0041 \mathrm{~ns}$ & 0,0048 & 0,8567 & 0,3925 \\
\hline Dummy of ownership system (DSist) & + & $0,0141^{*}$ & 0,0104 & 1,3519 & 0,1777 \\
\hline$R$-squared & & 0,9883 & & & \\
\hline Adjusted $R$-squared & & 0,9877 & & & \\
\hline Log-likelihood & & 496,213 & & & \\
\hline$F$-statistic & & 1608,547 & & & \\
\hline Prob. $($ F-statistic) & & 0,0000 & & & \\
\hline Exp Signe
\end{tabular}

Abbreviations: Exp. Sign $=$ Expected Significance; $\mathrm{ns}=$ non significant

Remarks: $* * *=$ significance at $\alpha=1 \% ; * *=$ significance at $\alpha=5 \% ; *$ significance at $\alpha=10 \%$

Source: Primary Data Analysis, 2018

The estimation of the profit function of self-ownership farmers and partnership farmers had an R-squared value of 0.9883 , meaning that $98.83 \%$ of the profit rate variable for beef cattle business could be explained by the variables in the model, while other factors outside the model described the remaining $1.17 \%$.

Based on the analysis of the profit function in Table 3, it shows that the variables significantly affect the profits of the beef cattle business of farmers with a confidence level of $99 \%(\alpha=0.01)$, including beef cattle production, depreciation cost of barn and equipment, price of calves, price of forage feed, price of concentrate feed, and wage labor. The variables having a significant effect on the $\alpha$ level of $10 \%$ are the type of beef cattle and ownership systems. The variables do not significantly affect the profits of beef cattle business because tcount is smaller than t-table, those are the variable price of cattle medicines, the price of supplement feed, education level, and membership of livestock groups. Explanation of the variables included in the analysis model of the profit of farmers' beef cattle business in the Special Region of Yogyakarta can explain below:

\subsection{Beef Cattle Production}

The value of t-count of beef cattle production variable of 3.3760 was greater than the t-table of 2.3428 at $\alpha$ level of $1 \%$, indicating that $\mathrm{H}_{0}$ was accepted, there was a real or individually-significantly affect the variables of beef cattle production and the profit of beef cattle business of farmers in Special Region of Yogyakarta; the coefficient value was positive at 0.0317 and had a significant effect. The results of this research study indicated that an increase in beef cattle production would increase the profits of beef cattle farmers both self-ownership farmers and partnership farmers by $0.0317 \%$.

Production of beef cattle obtained from Average Daily Gain/ADG. The calculation of the selling price of beef cattle at the animal market based on posture and weight. Beef cattle with great posture had a higher selling price than Beef cattle with a small position. The recommended weight to get the optimal carcass for Simmental and Limousine was more than $500 \mathrm{~kg}$; far above the weight of a local cattle (Ongole Cattle/PO) that was equal to $400 \mathrm{~kg}$ [16]. This result was in line with research study conducted by [25], which stated that Simmental cattle fattening by the farmer by improvements in feed would increase the ADG by $0.83 \mathrm{~kg} / \mathrm{head} / \mathrm{day}$, and would add a profit of IDR 7,733,550 per breeding period.

\subsection{Depreciation Cost of Barn and Equipment}

The t-count value of depreciation cost variable of barn and equipment of 2.6083 was bigger than t-table of 2.3428 at the $\alpha$ level of $1 \%$, indicated that $\mathrm{H}_{0}$ was accepted; there was a real or individually-significantly relationship between the depreciation of cost variable of barn and equipment and the profit of the beef cattle business of farmers in Special Region of Yogyakarta; the coefficient value was negative at 0.0139 and had a significant effect. The results of this research study indicated that an increase in the cost of barn and equipment depreciation would reduce the profits of beef cattle farmers both self-ownership farmers and partnership farmers by $0.0139 \%$.

Spending for depreciation of cage and equipment for self-ownership respondents as well as partnership respondents after tabulated not allocated too much. In terms of the amount of spent, partnership farmers were slightly bigger than self-ownership farmers. The cost of depreciation allowed farmers to repair the damage of the barn and buy new equipment so that it indirectly influenced the process of breeding livestock. The consequence of the allocation of depreciation cost caused the profits decreased because there was some profit set aside for the next fattening period. 
Ferdian Achmad et al., 2019. Factors Affecting Profit Analysis of Small-Scale Beef Cattle Farmers in the Special Region of Yogyakarta, Indonesia / American-Eurasian Journal of Sustainable Agriculture. 13(2): 1-12. DOI: 10.22587/aejsa.2019.13.2.1

The analysis results of [14] on beef cattle breeding in East Java (Probolinggo and Malang) and [11] in Wonogiri District showed that the cost of depreciation of the barn did not significantly affect the profits of the beef cattle business, because not all farmers set aside and allocated in significant amounts.

\subsection{The Price of Calves (Fattening Cattle)}

The coefficient value of beef cattle variable was negative and significant at the $\alpha$ level of $1 \%$ which was equal to -0.5549 , indicating that the price of beef cattle would affect the profit rate of beef cattle business by small-scale farmers in Special Region of Yogyakarta. The higher the price of feeder cattle, the lower the profit of beef cattle farmers; both self-ownership farmers and partnership farmers was $0.5549 \%$. The cost of beef cattle at the animal market was the price of selling beef cattle according to physical appearance. The higher the rate of feeder cattle which would fatten, the higher the profit expected, with the consequence that the farmer had to spend a large number of purchase costs.

Non-fixed costs that were the purchase of feeder cattle was the highest costs in beef cattle fattening. Price of feeder cattle each year has experienced fluctuations (up/down) depending on the season and religious holidays (Eid al-Adha). The more feeder cattle fattened, the higher the production costs, especially on non-fixed costs [35]. This was related to the small-scale business of farmers, in which each addition of 1 Animal Unit (AU) of beef cattle breeding will increase the income/profit of beef cattle business [11], with other input requirements fulfilled, such as forage feed and concentrate feed. According to [18], the advantage of a beef cattle business influenced by the number of beef cattle. [32] also revealed that the profit of fattening beef cattle affected by the number of fattened cattle and the purchase price of feeder cattle. The cost of beef cattle also affects earnings at the end of the fattening period [1].

The fattening cattle used by farmers in the Special Region of Yogyakarta were very varied; those were Ongole Breed cattle (PO), Simmental cattle, Limousine cattle, and Brahman cattle. The increase in the price of feeder cattle at the animal market would have a significant effect on the profit received by farmers, because farmers tend to buy high quality and expensive beef cattle to get a good increase in ADG, with considering the availability of capital and barn capacity.

\subsection{The Price of Forage Feed}

The coefficient value of the variable of forage feed price was negative and significant at the $\alpha$ level of $1 \%$ which was equal to -0.1374 , indicating that the price of forage feed (calculated) influenced the profit rate of the beef cattle business in Special Region of Yogyakarta. The more forage feed inputs used by farmers, the more it would affect the profit because farmers and their family members would spend more energy and time gathering forage feed even though it was comparable to the increase in the ADG of beef cattle.

In the field, almost all farmers did not pay for the purchase of feed because forage feed (grass, straw) were obtained by gathering for themselves on vacant land and around the yard, both near and far from the farmers' house. The purchase of forage feed was only made during the dry season by a minority of the farmers in Gunungkidul Regency because they domiciled on hillsides. The result of the analysis of the forage variables from this research study was in line with the research study conducted by [32,11, and 22] which suggested that forage price hurt the profit of beef cattle.

\subsection{The Price of Concentrate Feed}

The regression coefficient value of the price variable of concentrate feed was negative at -0.0456 and was individually and significantly affect on the profit rate of the beef cattle business in Special Region of Yogyakarta at the $\alpha$ level of $1 \%$. The higher the price of concentrate feed, the higher the costs spending on purchasing concentrates feed that would reduce the profit of beef cattle fattening business. The results of interviews with respondents showed that the concentrate given as additional feed for beef cattle requires additional capital because it had to purchase at the store, different from forage feed that could be gathered by themselves. The results of the analysis in this research study were in line with the research study conducted by [9], which stated that the variable of concentrate feed was negative and significantly affected the profits of beef cattle fattening in Purwodadi Regency and Grobogan Regency, also in Wonogiri District [11].

\subsection{The Price of Cattle Medicine}

The coefficient value of the price variable of livestock medicine at -0.0050 had a t-statistic value smaller than $\mathrm{t}$-table of 1.2852, indicating that $\mathrm{H}_{1}$ was accepted; there was no real or significant relationship between the variables of livestock medicine and the profit rate of the beef cattle business in Special Region of Yogyakarta. The price of livestock medicines that did not affect the profits of fattening beef cattle business in this research study was due to the results of interviews with 240 respondents who were not found a severe problem of disease that fatally attacked beef cattle during breeding so that the costs spending were relatively small or even in some 
Ferdian Achmad et al., 2019. Factors Affecting Profit Analysis of Small-Scale Beef Cattle Farmers in the Special Region of Yogyakarta, Indonesia / American-Eurasian Journal of Sustainable Agriculture. 13(2): 1-12. DOI: $10.22587 /$ aejsa.2019.13.2.1

farmers there was almost no spending on medicines. This was in line with the research study conducted by [23 and 11], which stated that medicine costs did not affect the profit, while different results were stated by [9] which argued that medicine affected the profit of beef cattle business.

\subsection{Wage Labor}

The regression coefficient of wage labor variable at -0.1536 on the self-ownership farmers and partnership farmers had a negative and significant effect on the profit rate of beef cattle business of small-scale farmers in Special Region of Yogyakarta, at the $\alpha$ level of $1 \%$. The wage for family worker/labor considered gave a negative influence on profit. This was related to the number of daily working hours which were mostly allocated by farmers in gathering grass and forage feed. The wage labor (calculated) of workers affect positively the profits of beef cattle farmers [32,11,22].

Opinion from the results of another research study that was in line with the argument of [9] which stated that wage labor had an adverse effect in which the higher the wages of labor, the higher the costs spent by farmers for labor; it would reduce the profit. According to [24], the factors that significantly and positively affected the amount of livestock ownership were agricultural land, breeding/business experience, and labor. Elements of agricultural land ownership, business experience, and the amount of availability of family labor were the factors that need to be considered to consider the number of beef cattle on beef cattle business.

Additional income from working as a farm laborer in the agricultural sector and from renting out agricultural equipment and machinery (off-farm income) also significantly increased the actual profits of beef cattle farmers. Some farmers did not have paddy fields or gardens, so by working as farm laborers during their spare time, they could get additional income to buy supplemental feed for their beef cattle [15].

\subsection{The Price of Supplement Feed}

The coefficient value of supplement price variable of 0.3492 was positive and had a t-statistic value smaller than t-table of 1.2852 indicating that $\mathrm{H}_{1}$ was accepted, meaning there was non-significant relationship individually between the variable supplements/hormones with the profit of beef cattle business of small-scale farmers in Special Region of Yogyakarta. This was because the proportion of feed supplement given by the respondent to beef cattle was not in large quantities and was only additional if the farmer had excess capital, especially for self-ownership farmers.

\subsection{Level of Education}

Educational level variable did not individually and significantly affect the profit of small-scale beef cattle business in the Special Region of Yogyakarta. This condition was following the opinion stated that the level of education did not significantly influence the level of profit $[28,1]$. It expected that having a higher level of education would make a person more rational in carrying out their business [15]. Small-scale beef cattle business in Special Region of Yogyakarta, both self-ownership farmers and partnership farmers, only used as a side job for savings so that beef cattle farmers tend to rely on the science of livestock farming which was inherited from generation to generation and did not need high education to be able to run it.

Based on data [4], the level of education of beef cattle farmers in the Special Region of Yogyakarta was relatively low of $33.42 \%$ did not graduate from elementary school/equivalent, $31.56 \%$ from elementary school/equivalent, $13.56 \%$ from junior high school, $18.1 \%$ from senior high school, and only $3.36 \%$ were able to finish up the higher education (Diploma/ Bachelor). Although farmers had varied levels of education, related to the technical skills of breeding/farming in the field of beef cattle farming, farmers tend to rely on experiences and habits that had performed for years.

\subsection{Type of Beef Cattle}

Type of beef cattle variable had a significant effect on the profit of small-scale beef cattle business in Special Region of Yogyakarta. The coefficient value of beef cattle type was positive at 0.0026 with a t-statistic value of 1.4546 bigger than t-table of $1.2852(\alpha=10 \%)$. This indicated that the kind of beef cattle in 240 respondents of beef cattle farmers in Special Region of Yogyakarta had a significant influence on the level of profit of small-scale beef cattle business in Special Region of Yogyakarta. The regression coefficient had a positive sign in accordance with the expected sign that if the farmers take care of the type of non-local cattle (Simmental/Limousine), then the farmers' profits would increase, compared to the local cattle (Ongole Breed cattle/PO), in the same period and quantity of feed.

\subsection{Livestock Group Membership}

Livestock group membership variable did not significantly influence the profits of the small-scale beef cattle business of farmers in Special Region of Yogyakarta even though the regression coefficient was positive 
Ferdian Achmad et al., 2019. Factors Affecting Profit Analysis of Small-Scale Beef Cattle Farmers in the Special Region of Yogyakarta, Indonesia / American-Eurasian Journal of Sustainable Agriculture. 13(2): 1-12. DOI: 10.22587/aejsa.2019.13.2.1

according to the expected sign. The ratio of livestock group membership was positive at 0.0041 , but because it was not significant, so it had no meaning. The value of t-statistic of this variable was 0.8567 smaller than the $t-$ table of 1.2852 .

The results of this analysis interpreted that the joining of some farmers in the group of beef cattle breeding was not able to give an influence on the increase in profit compared to some farmers who not joined the group. This was because the primary input that directly determined the success of a beef cattle fattening business was feed (forage and concentrate). Membership in a group of livestock only facilitated farmers in receiving information, cattle recording administration, marketing, counselling guidance, and access to government programs and assistance.

\subsection{Ownership System}

Ownership system variable between the self-ownership system and partnership system according to the results of the analysis had a significant influence on the $\alpha$ level of $10 \%$ on the profits of the small-scale beef cattle business of farmers in Special Region of Yogyakarta. The coefficient of livestock ownership system was positive at 0.0141 with at-stat value variable of 1.3519 which was more significant than t-table of 1.2852.

This indicated that the ownership system variable in a total of 240 respondents of beef cattle farmers in Special Region of Yogyakarta had a significant influence on the profit rate of the beef cattle business in Special Region of Yogyakarta. The regression coefficient was positive following the expected sign. The profit of farmers with the self-ownership system was more significant than the partnership system because selfownership farmers had advantages in terms of capital. The results of this research study on 240 respondents located in 4 regencies in Special Region of Yogyakarta showed things that had the same conditions; the difference in the profit calculation of self-ownership farmers was IDR 2,620,374/tail/period on average which was higher than the profit of the comparison variable or partnership farmers of IDR 1,904,776/tail/period from the breeding period.

\section{CONCLUSION}

Based on the results of the analysis of this research study, it can be concluded that the profit of small-scale fattening beef cattle on self-ownership farmers in Special Region of Yogyakarta were higher than the partnership farmers. Total revenue (TR) of small-scale beef cattle fattening have an average of IDR 25,725,200/farmer/fattening period for self-ownership farmers and IDR 21,775,400 /farmer/fattening period for partnership farmers. Total cost (TC) have an average of IDR 23,104,826 /farmer/fattening period for selfownership farmers and IDR 19,870,624 /farmer/fattening period for partnership farmers. So that, the percentage of profit $(\pi)$ obtained by each farmer in one period of fattening is IDR 2,620,374 for self-ownership farmers, and IDR $1,904,776$ for partnership farmers, which indicates that the system of self-ownership and partnership is financially profitable $(\pi>0)$.

Factors that affecting the profit of small-scale beef cattle farmers negatively included depreciation cost of barn and equipment, the price of calves (fattening cattle), the price of forage feed, price of concentrate feed, and wage labor. The added value of the five variables tends to reduce the profits obtained by the farmers. While the factors that influenced positively were the variable of the amount of beef cattle production, type of beef cattle, and cattle ownership system, the addition of the number and fulfilment of the three variables would increase the profit of beef cattle farmers.

\section{Acknowledgements}

The authors would like to thanks to the Ministry of the Agriculture Republic of Indonesia for facilitating and supporting this research.

\section{REFERENCES}

[1] Aiba, A., J.C. Loing., B. Rorimpandey., and L.S. Kalangi. (2018). Analisis Pendapatan Usaha Peternak Sapi Potong di Kecamatan Weda Selatan Kabupaten Halmahera Tengah. Jurnal Zootek., 38(1): 149-159. https://ejournal.unsrat.ac.id/index.php/zootek/article/viewFile/18622/18142

[2] Amrawaty, A.A., S.N. Sirajuddin., V.S. Lestari., and A. Abdullah. (2017). Gender Analysis on Beef Cattle Farm. American-Eurasian Jurnal of Sustainable Agriculture., 11(6): 42-45. http://www.aensiweb.net/AENSIWEB/aejsa/aejsa/2017/Nov-Dec/42-45.pdf

[3] Central Bureau of Statistics (BPS). (2013). Agribisnis Usaha Rumah Tangga Budidaya Sapi dan Target Swasembada. Badan Pusat Statistik. Jakarta.

[4] Central Bureau of Statistics (BPS). (2017). Hasil Survey Struktur Ongkos Usaha Peternakan 2017 (SOUT 2017) Provinsi Daerah Istimewa Yogyakarta. Badan Pusat Statistik. DI Yogyakarta. 
Ferdian Achmad et al., 2019. Factors Affecting Profit Analysis of Small-Scale Beef Cattle Farmers in the Special Region of Yogyakarta, Indonesia / American-Eurasian Journal of Sustainable Agriculture. 13(2): 1-12. DOI: 10.22587/aejsa.2019.13.2.1

[5] Darmawi, D. (2012). Peranan Tenaga Kerja Keluarga Dalam Usaha Pemeliharaan Sapi di Kabupaten Tanjung Jabung Barat. Jurnal Ilmiah Ilmu-Ilmu Peternakan., 15(2): 48-58. https://onlinejournal.unja.ac.id/jiip/article/view/1590/1047

[6] Dinas Pertanian (Distan). (2017). Laporan Tahunan. Annual Report. Tahun 2017. Dinas Pertanian Provinsi Daerah Istimewa Yogyakarta.

[7] Dwiastuti, R. (2017). Metode Penelitian Sosial Ekonomi Pertanian. UB Press - Malang. pp. 169-170.

[8] Ekowati, T., E. Prasetyo., and M. Handayani. (2018). The Factors Influencing Production and Economic Efficiency of Beef Cattle Farm in Grobogan Region, Central Java. Journal of Indonesian Tropical Animal Agriculture., 43(1): 76-84. DOI: https://doi.org/10.14710/jitaa.43.1.76-84

[9] Ginting, A.B. (2012). Faktor-Faktor yang Mempengaruhi Pendapatan Usahatani Padi dan Usaha Penggemukan Sapi Potong (Studi Kasus Kabupaten Purwodadi dan Kabupaten Grobogan). Jurnal Penelitian Bidang Ilmu Pertanian., 11(3): 106-129.

[10] Haloho, R.D., S.I. Santoso., S. Marzuki., W. Roessali., and A. Setiadi. (2013). Profit Function Analysis of Dairy Cattle Farming in Getasan and West Ungaran Districts, Semarang Regency. Journal of Indonesian Tropical Animal Agriculture., 38(2): 116-122. DOI: https://doi.org/10.14710/jitaa.38.2.116122

[11] Happy and, D. (2017). Analysis of Operating Profit Small Fattening Beef Cattle in Wonogiri District. Jurnal Ilmiah Peternakan Terpadu., 5(2): 33-39. DOI: http://dx.doi.org/10.23960/jipt.v5i2.p33-39

[12]Hartono, B., and E.S. Rohaeni. (2014). Contribution to Income of Traditional Beef Cattle Farmer Households in Tanah Laut Regency, South Kalimantan, Indonesia. Livestock Research for Rural Development., 26(8): 1-8. http://www.lrrd.org/lrrd26/8/hart26141.htm

[13] Isyanto A.Y., M.I. Semaoen., N. Hanani., and Syafrial. (2013). Measurement of Farm Level Efficiency of Beef Cattle Fattening in West Java Province, Indonesia. Journal of Economics and Sustainable Development., 4(10): 100-104. https://www.iiste.org/Journals/index.php/JEDS/article/view/6518/6538

[14] Kalangia, L.S., Y. Syaukat., S.U. Kuntjoro., and A. Priyanti. (2016). Factors Affecting Profit Analysis of Beef Cattle Farming in East Java, Indonesia. Livestock Research for Rural Development., 28(12): 1-8. http://www.lrrd.org/lrrd28/12/kala28226.htm

[15] Kalangi, L.S., Y. Syaukat., S.U. Kuntjoro., and A.Priyanti. (2014). Technical Efficiency of Beef Cattle Breeding Business in East Java Province. MEDIA PETERNAKAN., 37(2): 136-142. DOI: 10.5398/medpet.2014.37.2.136

[16] Ministry of Agriculture (MoA). (2009). Blue Print Kegiatan Prioritas Program Swasembada Daging Sapi Tahun 2014. Direktorat Jenderal Peternakan dan Kesehatan Hewan. Kementerian Pertanian. Jakarta.

[17] Ministry of Agriculture (MoA). (2015). Rencana Strategis Kementerian Pertanian Tahun 2015-2019. http://www1.pertanian.go.id/file/RENSTRA_2015-2019.pdf (accessed 22 October 2018)

[18] Ministry of Agriculture (MoA). (2017). Statistik Pertanian. Agricultural Statistics 2017. Pusat Data dan Sistem Informasi Pertanian. Kementerian Pertanian RI - Jakarta.

[19] Molefi, S.H., and C.A. Mbajiorgu. (2017). Assessing The Potential of Beef Cattle Farming as Contributor to Income of Cummunal Households of Chief Albert Luthuli Municipality in Mpumalanga Province, South Africa. Indian J. Anim. Res. 51(2): 350-357. DOI:10.18805/ijar.9552

[20] Mosher, A. T. (1991). Menggerakkan dan Membangun Pertanian. Syarat-Syarat Pokok Pembangunan dan Modernisasi. Jakarta: CV Yasaguna.

[21] Nurlaelah, S., S. Rohani., and S.N. Sirajuddin. (2018). The Allocation Time of Women to Livestock Business in Takalar Regency of South Sulawesi Province, Indonesia. AMERICAN-EURASIAN JURNAL OF SUSTAINABLE AGRICULTURE., 12(2): 1-4. DOI: 10.22587/aejsa.2018.12.2.1

[22] Otampi, R.S., F.H. Elly., M.A. Manese., and G.D. Lenzun. (2017). Pengaruh Harga Pakan dan Upah Tenaga Kerja Terhadap Usaha Ternak Sapi Potong Petani Peternak di Desa Wineru Kecamatan Likupang Timur Kabupaten Minahasa Utara. Jurnal Zootek., 37(2): 483-495. https://ejournal.unsrat.ac.id/index.php/zootek/article/viewFile/16786/16288

[23] Rahayu, E.T. (2013). Analisis Pendapatan Usaha Ternak Sapi Perah di Kecamatan Cepogo Kabupaten Boyolali. Jurnal Sains Peternakan., 11(2): 99-105. DOI: http://dx.doi.org/10.20961/sainspet.v11i2.4852

[24] Sahala J., R. Widiati., and E. Baliarti. (2016). Analisis Kelayakan Finansial Usaha Penggemukan Sapi Simmental Peranakan Ongole dan Faktor-Faktor yang Berpengaruh Terhadap Jumlah Kepemilikan pada Peternakan Rakyat di Kabupaten Karanganyar. Buletin Peternakan., 40(1): 75-82. DOI: https://doi.org/10.21059/buletinpeternak.v40i1.9823

[25] Sahara, D., Muryanto., and Subiharta. (2015). Keuntungan Pembesaran Sapi Peranakan Simmental Melalui Perbaikan Pakan di Kabupaten Semarang. Jurnal Pengkajian Dan Pengembangan Teknologi Pertanian., 18(2): 169-179. DOI: 10.21082/jpptp.v18n2.2015.p\%p 
Ferdian Achmad et al., 2019. Factors Affecting Profit Analysis of Small-Scale Beef Cattle Farmers in the Special Region of Yogyakarta, Indonesia / American-Eurasian Journal of Sustainable Agriculture. 13(2): 1-12. DOI: $10.22587 /$ aejsa.2019.13.2.1

[26] Sarma, P.K., and J.U. Ahmed. (2011). An Economic Study of Small Scale Fattening Enterprise of Rajbari District. J. Bangladesh Agril. Univ., 9(11): 141-146. DOI: https://doi.org/10.3329/jbau.v9i1.8756

[27] Scheltema, A.M.P.A. (1985). Bagi Hasil di Hindia Belanda, Jakarta, Yayasan Obor Indonesia.

[28] Setiani H.S., S. Nur., and O.E. Djatmiko. (2013). Analisis Perbandingan Pendapatan Peternak Kelompok Penerima Bantuan Pemerintah dan Kelompok Mandiri pada Kelompok Ternak Sapi Potong di Kabupaten Purbalingga. Jurnal Ilmiah Peternakan., 1(2): 639-646.

[29] Sirajuddin, S.N., A.R. Siregar., and P. Mappigau. (2014). Differences Among Cattle Farmers' Income From Partnership and Non-Partnership Systems. World Journal of Environmental Biosciences., 6(4): 20-23.

[30] Sirajuddin, S.N., S. Nurlaelah., A. Amrawaty., T. Amrullah., S.T. Rohani., and I.M. Saleh. (2017). Relationship Between Farmers Characteristic and Income from Beef Cattle with The Traditional ProfitSharing. American-Eurasian Jurnal of Sustainable Agriculture., 11(5): 29-34. http://www.aensiweb.net/AENSIWEB/aejsa/aejsa/2017/Sept-oct/29-34.pdf

[31] Soekartawi. (2003). Prinsip Ekonomi Pertanian. Rajawali Press. Jakarta.

[32] Sunarto, E.E., O.H. Nono., U.R. Lole., and H.Y. Sikone. (2016). Analisis Finansial Sistim Penggemukan Sapi Potong oleh Perusahaan dan Peternakan Rakyat di Kabupaten Kupang. Journal of Animal Science., 1(4): 46-49. DOI: https://doi.org/10.32938/ja.v1i04.257

[33] Utami, H.D., A. Yakin., and A.P. Seruni. (2018). Determinants Affecting on Smallholder Madura Cattle Farming at Pamekasan Regency, East Java, Indonesia. Iop Conf. Ser.: Earth Environ. Science.. 119: 19. DOI: $10.1088 / 1755-1315 / 119 / 1 / 012063$

[34] Wibowo, B., and Sumanto. (2013). Pola Budidaya dan Gaduhan Usaha Sapi Potong di Kawasan Perkebunan Sawit Rakyat di Provinsi Lampung. Proceeding Seminar Nasional Teknologi Peternakan dan Veteriner 2013. Balitnak Ciawi - Bogor.

[35] Widi, T.S.M. (2004). Livestock Sharing Arrangements in the Province of Yogyakarta Special Region Indonesia. Thesis, Animal Science. Wageningen University. Netherland.

[36] Yotopoulos, P.A., and J.B. Nugent. (1976). Economics of Development (Empirical Investigations) Harper International Edition. Harper \& Row Publishers. New York.

[37] Yuliati, I., Z. Fanani., and B. Hartono. (2014). Analisis Profitabilitas Usaha Penggemukan Sapi Potong, Desa Gunungrejo, Kecamatan Kedungpring, Kabupaten Lamongan. Jurnal Universitas Brawijaya. 